\title{
Exhumation of a migmatite complex along a transpressive shear zone: inferences from the Variscan Juzbado-Penalva do Castelo Shear Zone (Central Iberian Zone)
}

\author{
Inês Pereira ${ }^{1,2 *}$, Rui Dias ${ }^{1,3}$, Telmo Bento dos $\operatorname{Santos}^{4}$ \& João Mata ${ }^{4}$ \\ ${ }^{1}$ Laboratório de Investigação de Rochas Industriais e Ornamentais da ECTUE, Convento das Maltezas, Estremoz, Portugal \\ ${ }^{2}$ Present address: School of Earth and Environmental Sciences, University of Portsmouth PO1 3QL, Portsmouth, UK \\ ${ }^{3}$ Instituto Ciências da Terra e Departamento de Geociências, Escola de Ciências e Tecnologia da Universidade de Évora, \\ 7000-671 Évora, Portugal \\ ${ }^{4}$ Instituto Dom Luiz, Faculdade de Ciências, Universidade de Lisboa, 1749-016 Lisboa, Portugal \\ (iD R.D., 0000-0003-1658-1690; J.M., 0000-0001-5769-7708 \\ *Correspondence: ines.pereira@port.ac.uk
}

\begin{abstract}
High-grade metamorphic rocks associated with S-type granites are recorded in the Central Iberian Zone, Iberian Variscides. Though most of these occur as inferred metamorphic core complexes affiliated with detachment faults, others, such as the Figueira de Castelo Rodrigo-Lumbrales Anatectic Complex, crop out between low-grade metamorphic rocks separated by steeply-dipping strike-slip shear zones, such as the Juzbado-Penalva do Castelo Shear Zone. Our structural analysis has been able to constrain two major deformation stages during the Variscan $\mathrm{D}_{3}$ : (a) $\mathrm{D}_{3 \mathrm{a}}$ ductile deformation event, with clear sinistral kinematic criteria; and (b) $D_{3 b}$ thrusting ductile-brittle deformation event. The petrological investigation confirmed the jump in metamorphic grade between the host rocks and the anatectic complex. $P-T$ estimates on calc-silicate rocks interlayered with the metapelites of the anatectic complex provided minimum metamorphic peak conditions of $T=761 \pm 50^{\circ} \mathrm{C}$ and $P=5.0 \pm$ $1.0 \mathrm{kbar}$. However, petrological modelling results show that $P-T$ conditions must have exceeded $T>800^{\circ} \mathrm{C}$. Both structural and geothermobarometric data support a two-step model for the exhumation of the Anatectic Complex, including a $5-8 \mathrm{~km}$ vertical exhumation along a $65-100 \mathrm{~km}$ horizontal displacement due to a simple shear-dominated transpression mechanism during the Variscan $\mathrm{D}_{3}$ events.
\end{abstract}

Supplementary material: The petrology data, mineral chemistry analyses of the calc-silicate units and EPMA analytical conditions, and the $P-T$ modelling methodology can be found at https://doi.org/10.6084/m9.figshare.c. 3785648

Received 16 December 2016; revised 9 April 2017; accepted 20 April 2017

Migmatites are a product of partial melting of deep to mid-crustal rocks under conditions of ultrametamorphism. Upon migmatization the crust suffers a significant strength reduction and their meltweakened domains tend to flow along crustal discontinuities constrained by pressure gradients associated with the dominant tectonic stresses (e.g. Jamieson et al. 2011). Upward migmatitic flow is an efficient way of crustal heat and mass transfer, ultimately leading to its emplacement at shallower crustal levels, locally generating very high metamorphic gradients.

The occurrence of high-grade metamorphic belts (i.e. metamorphic core complexes and/or gneiss domes) along low-dipping faults or shear zones in between low-grade metamorphic units is well established in the literature. Several models have been proposed for the exhumation of such high-grade complexes, namely channel flow (e.g. Hodges et al. 2001; Harris 2007; Searle 2013), extensional tectonics (e.g. Rey et al. 2009; Horton \& Leech 2013), buoyancy-driven flow (e.g. Teyssier \& Whitney 2002; Whitney et al. 2004) and late-orogenic gravitational/orogenic collapse (e.g. Martínez Catalán et al. 2007; Bento dos Santos et al. 2010, 2015; Gradim et al. 2014).

In the Variscan Central Iberian Zone (CIZ), high-grade metamorphic rocks and the associated S-type granites are known to be in contact with low-grade metamorphic units (e.g. Tormes Dome, Escuder Viruete et al. 1994; Escuder Viruete 1999; South Salamanca detachment, Díez Balda et al. 1995; Porto-Viseu Metamorphic Belt, Valle Aguado et al. 2005, 2007; Mindelo
Migmatite Complex, Silva 2014). The exhumation of these highgrade metamorphic belts, associated with gently-dipping shear zones, has been explained by different mechanisms, such as extensional collapse of the Iberian Variscan Massif (Valle Aguado et al. 2010; Azevedo \& Valle Aguado 2013), channel flow followed by extrusion tectonics (Rodrigues et al. 2013) and crustal thinning, as the result of normal faulting (Ribeiro et al. 1990).

In the CIZ, high-grade metamorphic complexes also occur in the vicinity of subvertical shear zones with predominant transcurrent kinematics. This is the case of the Figueira de Castelo Rodrigo-Lumbrales Anatectic Complex (FCR-LAC; including both migmatites and anatectic granites) bounded by the Juzbado-Penalva do Castelo Shear Zone (JPCsz; Carvalhosa 1960; Figuerola \& Parga 1968; Iglesias \& Ribeiro 1981). The exhumation mechanism of this complex is highly debated and has been considered either as the result of the sinistral transpression induced by the $D_{3}$ Variscan regional event (Pereira 2014) or the product of the extensional orogenic collapse along a low-dipping major shear zone during the regional $\mathrm{D}_{2}$ deformation event (Fernández \& Pereira 2016).

Here, a petrological, mineral chemistry and structural analysis study is presented and discussed in order to characterize the JPCsz and associated migmatites. The $P-T$ metamorphic evolution is modelled and combined with the structural data in order to propose an evolution model for the exhumation of the FCR-LAC in the geodynamic context of the Iberian Variscides. 
Ribeiro, A., Quesada, C. \& Dallmeyer, R. D. 1990. Geodynamic evolution of the Iberian Massif. In: Dallmeyer, R.D. \& Martínez-Garcia, E. (eds) Pre-Mesozoic Geology of Iberia. Springer-Verlag, Berlin, 397-410.

Ribeiro, A., Munhá, J. et al. 2007. Geodynamic evolution of the SW Europe Variscides. Tectonics, 26, TC6009.

Ribeiro, M.L. 2001. Notícia Explicativa da Carta Geológica Simplificada do Parque Arqueológico do Vale do Côa. Ed. Parque Arqueológico do Vale do Côa, Vila Nova de Foz Côa, 71.

Ribeiro, M.L. \& Silva, A.F. 2000. Carta Geológica Simplificada do Parque Arqueológico do Vale do Côa. Instituto Geológico e Mineiro, Ed. Parque Arqueológico do Vale do Côa. Vila Nova de Foz Côa (map).

Rodrigues, J.F., Bento dos Santos, T. et al. 2013. Deformação não-coaxial na Faixa Metamórfica Porto-Viseu: Détachment extensional ou par thrust/ underthrust contracional? In: Livro de Actas da $9^{\text {a }}$ Conferência Anual do GGET-SGP, Porto, Portugal, 131-134.

Rodríguez-Fernández, L.R. (ed.) 2004. Mapa Geológico de España a escala 1:2.000.000. In: Vera, J.A. (ed.) Geología de España. SGE-IGME, Madrid (map).

Romão, J., Metodiev, D., Dias, R. \& Ribeiro, A. 2013. Evolução geodinâmica dos sectores meridionais da Zona Centro-Ibérica. In: Dias, R., Araújo, A., Terrinha, P. \& Kullberg, J.C. (eds) Geologia de Portugal, vol. 1 : Geologia Pré-mesozóica de Portugal. Escolar Editora, Lisboa, 206-257.

Saint Blanquant, M., Tikoff, B., Teyssier, C. \& Vigneresse, J.L. 1998. Transpressional kinematics and magmatic arcs. In: Holdsworth, R.E., Strachan, R.A. \& Dewey, J.F. (eds) Continental Transpressional and Transtensional Tectonics. Geological Society, London, Special Publications, 135, 327-340, https://doi.org/10.1144/GSL.SP.1998.135.01.21

Sanderson, D. \& Marchini, W. 1984. Transpression. Journal of Structual Geology, 6, 449-458.

Sawyer, E.W. (ed.) 2008. Atlas of migmatites. Canadian Mineralogist, Special Publication, 9, NRC Research Press, Ottawa, Ontario.

Schulmann, K., Schaltegger, U., Jezek, J., Thompeson, A.B. \& Edel, J. 2002. Rapid burial and exhumation during orogeny: Thickening and synconvergent exhumation of thermally weakened and thinned crust (Variscan Orogeny in Western Europe). American Journal of Science, 302, 856-879.

Searle, M. 2013. Crustal melting, ductile flow, and deformation in mountain belts: Cause and effect relationships. Lithosphere, 8, 547-554.

Silva, A. \& Ribeiro, M.L. 1994. Carta Geológica de Portugal na Escala 1:50 000 e Notícia Explicativa da Folha 15-B (Freixo de Espada à Cinta). Instituto Geológico e Mineiro, Lisboa.

Silva, M.A. 2014. Petrogenesis of a variscan migmatite complex (NW Portugal): petrography, geochemistry and fluids. $\mathrm{PhD}$ thesis, Universidade do Porto, Porto.

Spear, F. \& Florence, F. 1992. Thermobarometry in granulites: Pitfalls and new approach. Precambrian Research, 55, 209-241.

Spear, F.S., Kohn, M. \& Cheney, J. 1999. P-T paths from anatectic pelites Pitfalls and new approaches. Precambrian Research, 55, 209-241.

Stevens, G., Clemens, J.D. \& Droop, G.T.R. 1997. Melt production during granulite-facies anatexis: experimental data from 'primitive' metasedimentary protoliths. Contributions to Mineralogy and Petrology, 128, 352-370.

Strachan, R., Treloar, P.J., Brown, M. \& D'Lemos, R.S. 1989. Cadomian terrane tectonics and magmatism in the Armorican Massif. Journal of the Geological Society, London, 146, 423-426, https://doi.org/10.1144/gsjgs 146.3.0423

Sylvester, A. 1988. Strike slip faults. Geological Society of America Bulletin, 100, 1666-1703.

Talavera, C., Montero, P., Martínez Poyatos, D. \& Williams, I.S. 2012. Ediacaran to Lower Ordovician age for rocks ascribed to the Schist-Graywacke Complex
(Iberian Massif, Spain): Evidence from detrital zircon SHRIMP U-Pb geochronology. Gondwana Research, 22, 928-942.

Ten Brink, U., Katzman, R \& Lin, J. 1996. Three-dimensional models of deformation near strike-slip faults. Journal of Geophysical Research, 101 16205-16220.

Teyssier, C. \& Tikoff, B. 1998. Strike-slip partitioned transpression of the San Andreas fault system: a lithospheric approach. In: Holdsworth, R., Strachan, R. \& Dewey, J. (eds) Continental Transpression and Transtension Tectonics. Geological Society, 135, 143-158, https://doi.org/10.1144/GSL.SP.1998.135. 01.10

Teyssier, C. \& Whitney, D.L. 2002. Gneiss domes and orogeny. Geology, 30, 1139-1142.

Thompson, A.B. \& Tracy, R.J. 1979. Model systems for anatexis of pelitic rocks. II. Facies series melting and reaction in the system $\mathrm{CaO}-\mathrm{KAlO} 2-\mathrm{NaAlO} 2$ Al2O3-SiO2-H2O. Contributions to Mineralogy and Petrology, 70, 429-438.

Tikoff, B. \& Teyssier, C. 1994. Strain modeling of displacement-field partitioning in transpressional orogens. Journal of Structural Geology, 16, 1575-1588.

Valle Aguado, B., Azevedo, M.R., Schaltegger, U., Martínez Catalán, J. \& Nolan, J. 2005. U-Pb zircon and monazite geochronology of Variscan magmatism related to syn-convergence extension in Central Northern Portugal. Lithos, 82, 169-184.

Valle Aguado, B., Azevedo, M.R., Nolan, J. \& Martinez Catalán, J.R. 2007. Extensão varisca D2 na cintura metamórfica de Porto-Viseu: dados geocronológicos 40Ar/39Ar. Abstract Book of XV Semana de Geoquímica e VI Congresso Ibérico de Geoquímica, Vila Real, 106, 166-169.

Valle Aguado, B., Azevedo, M.R., Santos, J.F. \& Nolan, J. 2010. O complexo migmatítico de Mundão (Viseu, norte de Portugal). VIII Congresso Nacional de Geologia. e-terra, 16, 4.

Valle Aguado, B., Azevedo, M.R., Medina, J., Nolan, J. \& Martínez Catalán, J.R. 2013. O papel da Zona de Cisalhamento Juzbado-Penalva do Castelo na intrusão de granitos variscos tardi-pós-D3 da região de Viseu (Zona CentroIbérica). In: IX Conferência Anual do GGET, Estremoz, 127-130.

Vigneresse, J.L. \& Tikoff, B. 1999. Strain partitioning during partial melting and crystallising felsic magmas. Tectonophysics, 312, 32-117.

Vigneresse, J.L., Barbey, P. \& Cuney, M. 1996. Rheological transitions during partial melting and crystallization with application to felsic magma segregation and transfer. Journal of Petrology, 37, 1579-1600.

Villar Alonso, P., Fernández Ruiz, J., Bellido, F., Carrasco, R.M. \& Rodriguez Fernández, L.R. 2000. Memoria del mapa geológico de España 1:50000, Lumbrales (Hoja 475), série magna, $1^{\mathrm{a}} \mathrm{ed}, 2^{\mathrm{a}}$ série, Madrid.

Villaseca, C., Merino, E., Oyarzun, R., Orejana, D., Pérez-Soba, C. \& Chicharro, E. 2014. Contrasting chemical and isotopic signatures from Neoproterozoic metasedimentary rocks in the Central Iberian Zone (Spain) of pre-Variscan Europe: Implication for Terrane analysis and Early-Ordovician magmatic belts. Precambrian Research, 245, 131-145.

Wang, J., Rubatto, D. \& Zhang, J. 2015. Timing of partial melting and cooling across the Greater Himalayan Crystalline Complex (Nyalam, Central Himalaya): In-sequence thrusting and its implications. Journal of Petrology, 56, $1677-1702$.

Whitney, D.L., Teyssier, C. \& Fayon, A.K. 2004. Isothermal decompression, partial melting and exhumation of deep continental crust. In: Grocott, J., McCaffrey, K. J. W., Taylor, G. \& Tikoff, B. (eds) Vertical Coupling and Decoupling in the Lithosphere. Geological Society, London, Special Publications, 227, 313-326, https://doi.org/10.1144/GSL.SP.2004.227.01.16

Wimmenauer, W. \& Brihni, I. 2007. 6. Migmatites and related rocks. IUGS Subcommission on the Systematics of Metamorphic, http://www.bgs.ac.uk SCMR/docs/papers/paper_6.pdf 